\author{
RESIM SANATINDA SANATÇININ KİMLİĞINİ YANSITAN BİR \\ TASARIM ELEMANI OLARAK ÇIZGi' ${ }^{1}$
}

\title{
LINE AS A DESIGN ELEMENT THAT REFLECS THE ARTIST'S IDENTITY IN THE ART OF PAINTING
}

\author{
Dalila ÖZBAY \\ Namık Kemal Üniversitesi, Güzel Sanatlar, Tasarım ve Mimarlık Fakültesi, Resim Bölümü, \\ Tekirdağ / Türkiye
}

Öz: Bir sanat yapıtını biçimlendiren özellikler arasında dönemin sosyal ve tarihsel boyutu, toplumun inançları ve düşünceleri, coğrafi şartları ile birlikte sanatçının kişiliği de önemlidir. Plastik sanatlarda, yapıtın temel unsuru olan çizgi sanatçının kimliğini yansıtmada büyük rol üstlenir. Günümüzdeki teknolojik gelişmeler ve yaşanan toplumsal değişmelere rağmen en önemli ifade elemanı olarak çizgi, ilk çağlardan bu yana varlığını sürdüren bir iletişim aracı olmuştur. Bir resmi oluşturan tasarım elemanları, nokta, çizgi, form, biçim, doku, 1şık ve renk olarak bilinmektedir. Ancak, nokta (iki çizginin kesiştiği yer olarak); form (çizgilerin sınırlandırdıkları ve ışığın etkisi ile hacim kazanabilen alan olarak); doku (alan içerisinde nokta ve/ veya çizgilerin toplamından elde edilen varyasyon olarak) ve renk bir yapıtı oluşturan tasarım elemanları olsalar da bu araştırmada sadece çizgi esas alınmıştır. Bu çalışmanın amacı, bir tasarım elemanı olan çizginin farklı biçim, yön, fonksiyonlara rağmen, dışavurumcu yapısını incelemek ve çizginin karakterini oluşturan sanatçı kimliğinin resim sanatındaki önemini vurgulamaktır.

Anahtar Kelimeler: Çizgi, Resim Sanatı, Sanatçının Kimliği, Dişa Vurumculuk
Abstract: Among the qualities that shape an artwork are the social and historical dimension, beliefs and thoughts of the society, geographical condition and also important is the artist's identity. In plastic arts, line, as the main element of the work, plays a great role in reflecting the artist's identity. Despite technological advances and social changes today, line, as an important element of expression, has been a means of communication since antiquity. The design elements that constitute a painting are dots, lines, forms, styles, texture, light, colour, and others, where dot is the intersecting point of two lines, form is the area bordered by lines and gaining volume by the effect of light, texture is the variation obtained by the sum of dots and/or lines in the area, and so on. The present study focuses on line as one of the most important design elements of a work of art, and attempts to analyse the expressive structure of the line as to emphasize the importance of the artist's identity, which generates the character of the line besides the line's different stylistic and directional functions as a design element.

Key Words: Line, art of Painting, Artist's Identity, Expressionism

Doi: 10.17365/TMD.2016716517

(1) Sorumlu Yazar: Dalila ÖZBAY, Namık Kemal Üniversitesi, Güzel Sanatlar, Tasarım ve Mimarlı Fakültesi, Resim Bölümü, Tekirdăg / Türkiye dalilaart@hotmail.com Geliş Tarihi / Received: 14.12.2015 Kabul Tarihi/Accepted: 28.02.2016 Makalenin Türü: Type ofarticle (Araştırma - Uygulama / Research -Application) Çıkar Çatışması / Conflict of Interest:Yok / None“Etik Kurul Raporu Yok - None of Ethics Committee" 

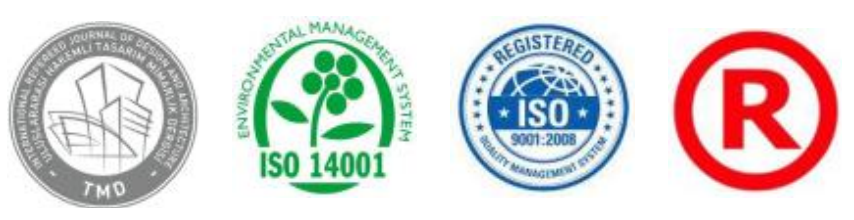

MTD

www.mtddergisi.com

ULUSLARARASI HAKEMLI TASARIM VE MIMARLIK DERGİSI

Ocak / Şubat / Mart / Nisan 2016 Sayı: 07 Kış İlkbahar

INTERNATIONAL REFEREED JOURNAL OF DESIGN AND ARCHITECTURE

January / February / March / April 2016 Issue: 07 Winter Spring

ID:100 K:156

ISSN Print: 2148-8142 Online: 2148-4880

(ISO 9001-2008 Belge No / Document No: 12879 \& ISO 14001-2004 Belge No / Document No: 12880)

(Marka Patent No / Trademark)

$(2015 / 04018$ - 2015 / GE - 17595)

\section{GíRIŞ}

Bir sanat yapıtını tasarlamak için hangi elemanları hangi kurallara göre düzenlemek gerekir sorusunun cevabı, çağlar boyunca sanatçıların önde gelen arayışlarından biri olmuştur. Bu doğrultuda çalışmalarını sürdüren sanatçılar, bilim insanları ve estetikçiler uzun süren gözlem ve araştırmalar sonucunda plastik sanatlarda temel tasarım ilkelerini ortaya koymuşlardır.

Bir edebiyat eserinde kelimelerin bir kompozisyonu oluşturacak biçimde düzenlenmesi gibi resmin de biçeminde çizgilerin armonisi, açıkkoyu değerleri ve rengin kuralları vardır. Bir resmin tasarımını oluşturabilmek için kullanılan temel fiziksel araçlar çizgi, 1şık ve renktir (Sutter, 1865: 4). Çizgi, resmin desenini oluşturmaktadır. Iş1k, resmin açık-orta-koyu değerini sağlamakta, ortaya çıkan kontrastlarla resme farklı bir ifade katmaktadır. Renk ise, kullanımına göre yarattığ 1 etki ile resimde algılamayı farklılaştırmaktadır. Bir tasarımda yer alan bu üç biçimsel ifade araçları (çizgi, 1şık, renk), tasarım ilkeleri ile birlikte bir resmi biçimlendirmektedir.

Bir resmi oluşturan bu fiziksel unsurlardan biri resmin geneline egemen olduğunda, resmin sonucunu etkilemektedir. O zaman resim, 'desen resmi' veya '1şı1k resmi' dir. Rengin kullanım yöntemi de bir resmi 'renk resmi' olarak nitelendirir. Son dönem sanat tarihçilerinden Sezer Tansuğ, "Resim iki boyutlu bir yüzey, yani bazen bir kağıt, bir duvar yüzeyi ya da bir tuval üzerinde oluşur. Resimde renk ve çizgi kendi başlarına ya da birlikte kullanılarak temel ifade unsurlarını meydana getirirler. Hangi çağa, hangi üsluba ait olursa olsun, resimde temel unsurlar daima çizgi ve renge dayanır. Bazı resim üsluplarında çizgi, bazılarında da renk egemendir. Söz gelişi, resmin eski çağlarında çizginin oynadığı başrol hemen göze çarpar. Buna karşılık, 19. Yüzyıl Avrupa'sinda renk, resme egemen olacak bir aşamaya erişmiştir.” der. (Tansuğ, 1973: 11).

Resim sanatında desen, bir yaratıcı eğilimin sonucunda ortaya çıkan ve çizgilerden oluşan görsel bir anlatım biçimi olarak, her zaman ve her çağda resmin ayrılmaz bir parçasıdır. Bedri Rahmi Eyüboğlu deseni "En ufak bir renk kaygisina girmeden yapilan resimlere desen denilir." diyerek tanımlamaktadır. Ona göre desen resmin çatısı, kuruluşu, iskeletidir (Eyüboğlu, 1986: 296-297). Desen, çocukluktan itibaren insanın kimliğini ve ruh durumlarını yansıtan bir unsur olarak bir fikri, iç dünyanın bir imajını veya bir duyguyu netleştirir ve bu fikrin, duygunun gerçekleşmesine yardımcı olur. $\mathrm{Bu}$ yüzden desen, kişinin duygularını, birikimlerini ve algısını yansitan jestüel eylemlerin toplamıdır. "Desen ile hareket arasındaki ilişkiler düşünülürse, resim yapmanın insanlığın en eski anlatım olanakları olduğu yargısına varırız. Parmağımızla havada bir atın dış çizgilerini göstermeye çalışsak bu henüz bir plastik sanat değildir, noksandır. Parmağın hareketiyle gösterilen konturun bir yüzeye işaret edilmesiyle desen elde edilmiş olur." (Akay, 


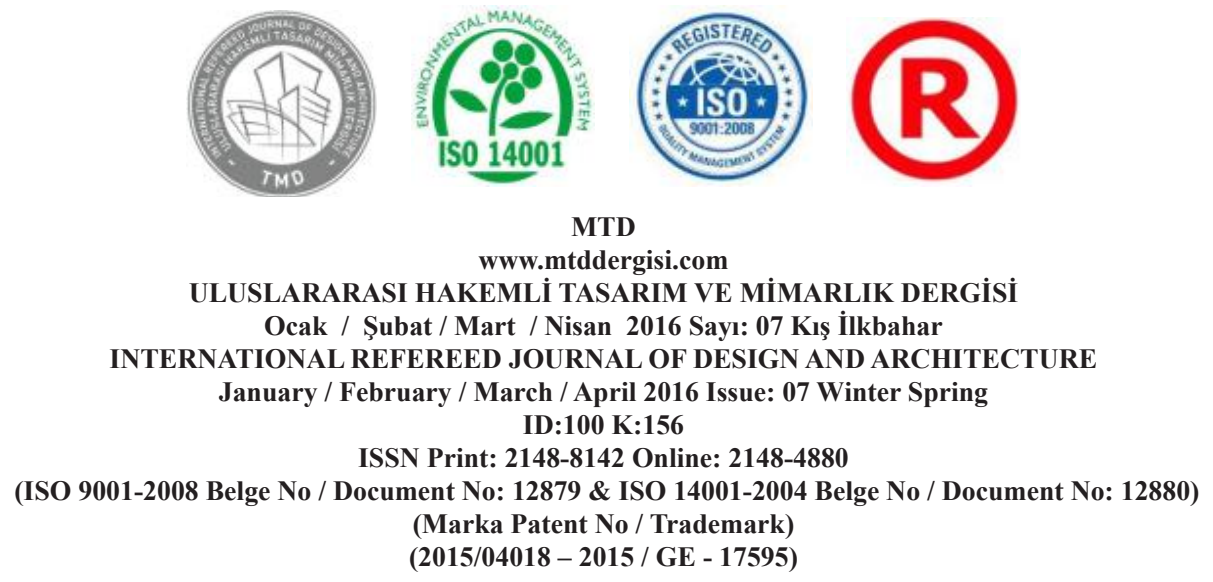

1976: 47). Deseni oluşturan çizgi, belirli bir yöne doğru birbirini takip eden ve hareket halinde olan noktaların birleşimidir. Hareketi sağlayan hız, basınç, jestüel ritim ve yön değişimlerine sebep olan unsurlar, çizginin karakterini oluş̧urmaktadır.

Çizginin yapısı kimi zaman aktif veya pasif, kimi zaman da statik veya dinamik, kesintisiz veya kesintili, eğri veya düz, güçlü veya narindir. Yapısı ne olursa olsun çizgi, sanatçı ve seyirci arasında görsel iletişimi sağlarken, aslında sanatçının en önemli ifade araçlardan biridir.

\section{2. ÇİGGININ FİZIKSEL YAPISI ve FONK- SIYYONLARI}

Çizginin fiziksel yapısında alanındaki uzunluk enden çok daha büyüktür. Bu alan genişledikçe veya daraldıkça, çizginin fiziksel yapısı değişmektedir. "Bir noktanın hareket durumunun dışında çizgi, uzunluk ve genişliği olan bir şekil olarak da tanımlanabilir. Ancak uzunluğuna oranla genişliği çok az olduğundan çizgi, tek boyutlu bir eleman olarak algılanmaktadır." (Doruk, 1980: 68). Genişlik veya uzunluk olarak bir çizgi biçimlendirilebiliyorsa, ton olarak da çizgi koyulaşır ya da açılır.

Çizginin bulunduğu çevrede diğer elemanlarla kurduğu ilişki, biçimsel yapısını etkilemektedir. Dış faktörler çizgiyi ince-kalın, uzun-kısa, açık-koyu göstermektedir. Çizginin yönü, başka çizgilerle oluşturduğu ritim, açık-koyu değeri veya rengi çizginin fiziksel yapısını tanımlamaktadır. $\mathrm{Bu}$ kriterlere çizginin sürekliliği de eklendiğinde aynı genişlikte devam eden çizgi, sadeliğini koruyan çizgi, inceliğini ve kalınlığını değiştiren çizgi, aynı ton değerini koruyan çizgi, açık-orta-koyu değerlerini değiştiren çizgi, sürekliliğini koruyan veya korumayan çizgi olarak ayrılmaktadır.

Sanatsal bir desen oluşturan çizgi, modle edilmiş çizgidir. Modle edilmiş çizgi, sürekliliği korumayan açık-koyu değerleri taşıyan çizgidir. Çizginin ince oluşu aydınlık alanı, açık renk veya hafif ve ince maddeyi anlatırken, kalın çizgi, gölge, koyu renk ve ağır maddeleri göstermektedir. Çizgi, espas, hareket, monotonluk, dağınıklık, görkemlilik, denge, boşluk, doluluk, form, hacim, ağırlık, optik yanılsama ve renk duygusunu uyandırabilen bir eleman olarak formu, ton değerini ve yöne göre etkisini değiştirebilmektedir.

Çizginin yarattığı etki çizginin fonksiyonu ile ilişkili ise çizginin taşıdığı ifade de sanatçının kişiliği ile ilişkilidir.

\section{3. ÇIZGGINIIN DIŞA VURUMCU YÖNÜ ve SANATÇI KIMLİĞí}

Dişa vurumcu anlayışta sanatçının yaşamına ve yaşantılarına yönelim söz konusudur. Buna göre sanatçının iç dünyasına açılan bir 'pencere' olarak sanat eseri, sanatçının duyguları ile değişime uğramış bir dünyayı anlatmaktadır (San, 2008: 79-80).

İsviçreli sanat tarihçisi Heinrich Wölfflin, "Sanat Tarihinin Temel Kavramları” adlı kitabında, 16. yüzyılın resimlerinde belirgin bir çizgi motifinin 


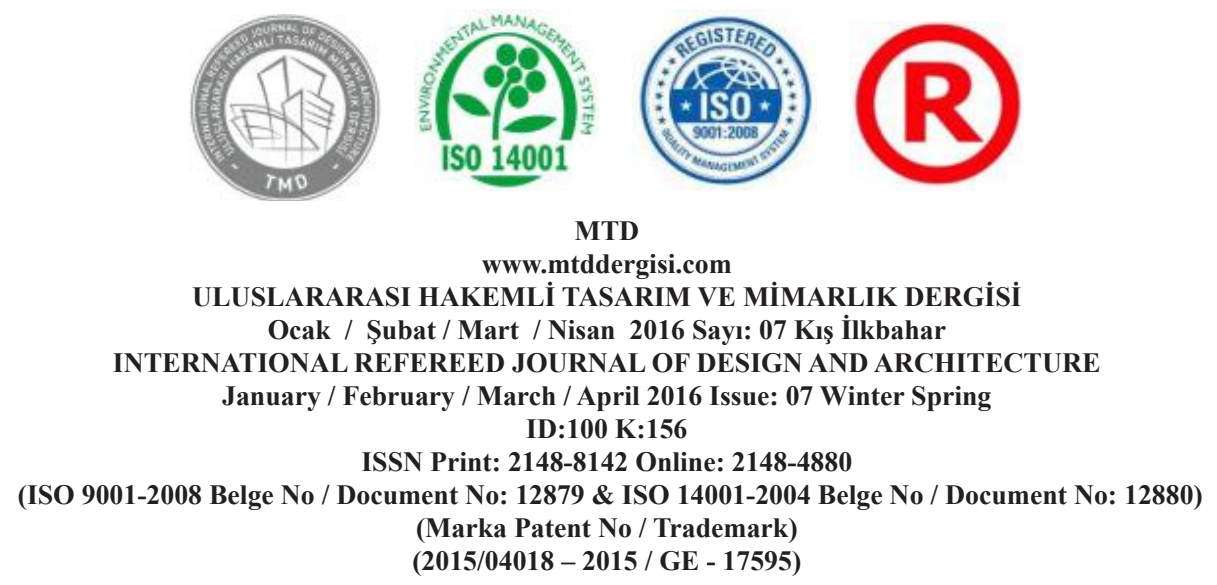

göze çarptığını ve çizginin ifadesiyle güzelliğin bir bütün olduğunu yazmıştır (Wölfflin, 2000: 44). Wölfflin'e göre çizgisel ifadenin gücü, en başta, klasik desenin konturundaki kesin ve mutlak etkisinden anlaşılmaktadır. Bu etki çizgiyi, nesnenin güzelliklerini içinde barındıran belirticisi haline getirir.

Sanatçı, çizgi aracılığıyla bir nesne veya bir kütlenin biçimsel yapısını aktarırken taşıdığı psişik enerjisini, düşüncesini ve duygularını da çizginin yapısına yansıtmaktadır. Sanatçının karakteri, içinde bulunduğu ruh hali, duyarlılığı ve duyguları çizgiye bir anlam katmaktadır. Sanatçının ölçülü ve kontrollü olması, spontane veya tutuk hareket etmesi çizgiye sadelik, sertlik, süreklilik, kırıklık, titreşim, canlılık, dinamizm veya durağanlık gibi özellikler kazandırmaktadır. Sanatçı, duygu ve düşünceleri, tutumları, hatta taşıdığ 1 toplumsal ve kültürel değerlerin etkisi ile de çizginin karakterini oluşturmaktadır.

Bilinçli olarak belirli bir görsellik amaçlansa da sanatçı çizgiyi kendi içyapısının etkileri ile birlikte oluşturduğu için çizgi, sanatçının karakterini yansitan ekspresif bir simge haline gelmektedir. Büyük sanatçıların çizgilerinin, adeta el yazısı gibi kendilerine has özellikler taşıdığını görürüz (Odabaş1, 2002: 37). Büyük ustalar çizgiyi tekdüzelikten sıyırarak ince, kalın, köşeli ya da yuvarlak olarak kendilerine özgü halde kullanırlar (Tansuğ, 1973: 14). 19. yüzy1lda yaşamış Alman ressam Ludwig Richter, üç arkadaşı ile birlikte aynı kompozisyonu resmettikleri halde ortaya dört farklı eserin çıkması ile yaşadığı deneyimin sonucunda, nesnel görüş diye bir şeyin asla var olmadığını ve her sanatçının renk ve şekilleri kendi kişiliğine göre, farklı yollarda kavradığını dile getirmiştir (Wölfflin, 2000: 11). Romanyalı yazar Constantin Zarnescu, "Brancuşi'nin Sanatının Kodlaması" adlı kitabında, sanatçının yapıtlarından seçtiği bir örneği ele alırken, bilinçaltının eseri adeta sanatçının imzalı plastik oto portresi haline getirdiğini söylemektedir (Zarnescu, 2007: 151).

Sanat tarihinde önemli sanatçıların yapıtları incelendiğinde, anlaşılmaktadır ki yön, kalınlık, koyuluk gibi fiziksel özelliklerin dışında çizginin karakterinde, onu oluşturan sanatçının jestüel ritmi belirleyicidir. Bu kritere göre çizgi çeşitliliği, dinamik, spontane, durağan, titreşimli ve düzensiz çizgi gibi sıralanabilir. Bu çizgilerin çeşitliliği, sanatçının özgünlüğünü oluşturan bir üslup ortaya koymaktadır.

Psikiyatri, insanın doğal yapısı ve çevresel etkilerin birleşimi sonucunda pasif-agresif, pozitif-negatif, depresif, narsist, obsesif gibi kişilik sınıflandırmalarını ortaya koymuştur (Jordan, 2011: 8) Sanatçının kişiliği ile eseri arasında sıkı bir bağ vardır. İyi bir sanat eserinde, sanatçının düşünerek, hesaplayarak koymadığı bazı zengin nitelikler de bulunur ve bunlar eleştirmenlerin yorumları ile ortaya çıkarılır (San, 2008: 86-87). Öyle ise her sanat eserinde dişa vurum söz konusudur. Bu yargıyı çizgi üzerinden birkaç örnekte analiz edebiliriz. 

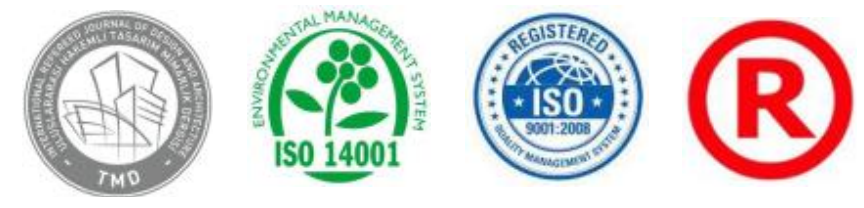

MTD

www.mtddergisi.com

ULUSLARARASI HAKEMLİ TASARIM VE MIMARLIK DERGISII

Ocak / Şubat / Mart / Nisan 2016 Sayı: 07 Kış İlkbahar

INTERNATIONAL REFEREED JOURNAL OF DESIGN AND ARCHITECTURE

January / February / March / April 2016 Issue: 07 Winter Spring ID:100 K:156

ISSN Print: 2148-8142 Online: 2148-4880

(ISO 9001-2008 Belge No / Document No: 12879 \& ISO 14001-2004 Belge No / Document No: 12880)

(Marka Patent No / Trademark)

(2015/04018 - 2015 / GE - 17595)

\subsection{Dinamik ve Spontane Çizgi}

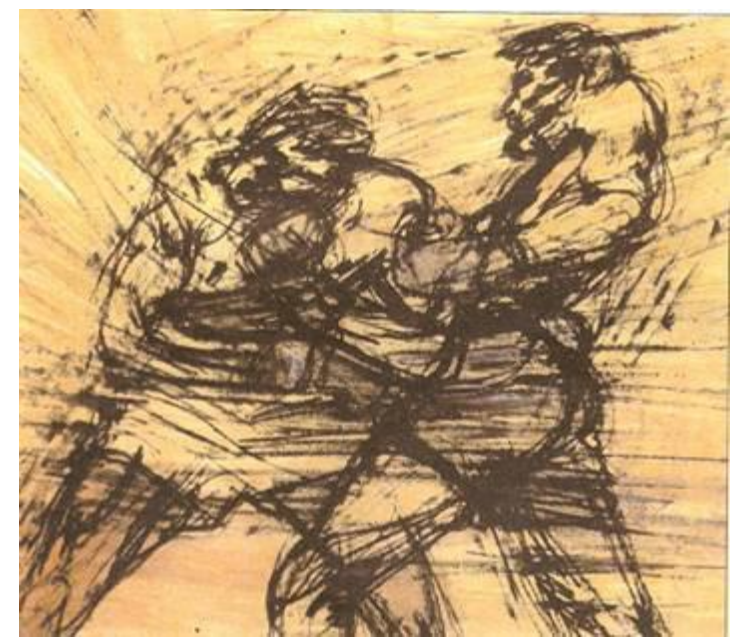

Şekil 1. Bob Peak „Kompozisyon”

Bob Peak "Kompozisyon" adlı eserinde hareketli bir tema seçmiştir. Çizgiyi kararlı ve spontane bir şekilde oluşturmuş görünmektedir. Zaten hızı anlatan bir konu seçmesi ile ve çizginin spontane oluşu, desenin dinamizmini artırmaktadır. Çizginin yer yer kopması ile (zemin üzerine kalemin düzenli kaymaması) kompozisyon içerisinde nokta etkisi vermektedir. Adeta yer yer bir bıçak zemini yarmış gibi okunmaktadır. Çizgilerin tekrarından oluşan ritim ise, konunun heyecanını artırmaktadır. Ancak formların hacminin oluşması için sanatçı desenin içerisinde çizgileri üst üste de getirmektedir. $\mathrm{Bu}$ etki, bir yandan hacmi oluştururken, diğer yandan alan/leke (büyük nokta) etkisi de sağlamaktadır. Çizginin kopuk oluşu, hızlı ve spontane bir hareketi göstermektedir. Bob Peak'e has olan bu coşkulu hareket, seyircide aksiyon ve heyecan hissi uyandırmaktadır. Sanatçının kişiliği burada çizginin hızından okunmaktadır.

\subsection{Durağan ve Spontane Çizgi}

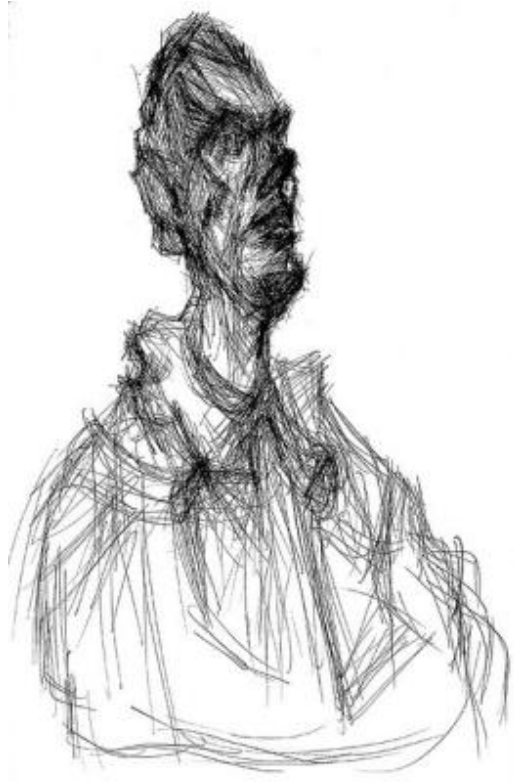

Şekil 2. Giacometti

$\mathrm{Bu}$ örnekte çizgi, kalınlaşma ya da incelme olmadan, ton değeri değişmeden adeta cetvelle çizilmiş gibi kullanılmıştır. Sanatçının çizgilerinin dikey olması bir yandan sükûnet, denge, kararlılık hissi verirken diğer yandan yükselme duygusu uyandırmaktadır. Burada, paralel düz çizgiler statik etki yaratıken çizgilerin toplamı düzen içerisinde ritim oluşturmakta ve bu toplamın sonucu sanatçının karakterini ortaya koymaktadır. Giacometti, resimlerini çizgisel bir ağ gibi oluşturma çabası ile renk tonlarıyla ya da gölgelerle uğraşmamış, resmin merkezinden başlayarak çizgileri geriye doğru çekip resimde farklı anlamlar aramıştır. Öyle çok çizgi kullanmıştır ki figür adeta tuvalin gerisine doğru itilmiştir. Bu çizgi yoğunluğu bir yandan huzursuzluk, sinirlilik ve heyecan 

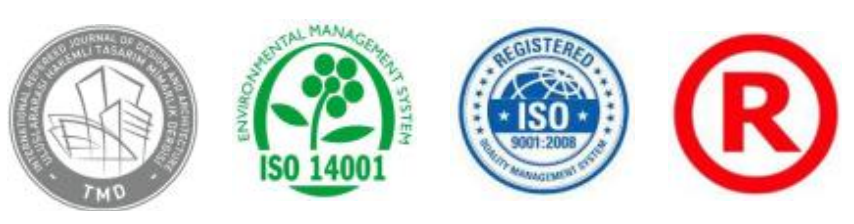

MTD

www.mtddergisi.com

ULUSLARARASI HAKEMLI TASARIM VE MIMARLIK DERGİSI

Ocak / Şubat / Mart / Nisan 2016 Sayı: 07 Kış İlkbahar

INTERNATIONAL REFEREED JOURNAL OF DESIGN AND ARCHITECTURE

January / February / March / April 2016 Issue: 07 Winter Spring ID:100 K:156

ISSN Print: 2148-8142 Online: 2148-4880

(ISO 9001-2008 Belge No / Document No: 12879 \& ISO 14001-2004 Belge No / Document No: 12880)

(Marka Patent No / Trademark)

$(2015 / 04018-2015 /$ GE - 17595)

duygularını gösterirken diğer yandan dinginliğ çağrıştırmakta, bütün insani duyguları bir arada yansıtma özelliği taşımaktadır.

\section{3. Titreşimli Çizgi}

Van Gogh örneğinde çizgi belirli bir hareket göstermektedir. Bunlar, kıvrak titreşimli ve bir düzen içerisinde yerleşmiş paralel çizgilerdir. Çizginin başlangıç ve bitiş noktaları arasında zemin üzerindeki yazıcının basıncı, kontrollü ve düzenli bir hareket göstermektedir. Kıvrak akımlarına rağmen çizgilerin paralel dizilişi, yine sanatçının harekete yansiyan ve aslında düşüncesinde var olan düzeni hissettirmektedir. Bu, Van Gogh'un iç enerjisinden kaynaklanan ve başka sanatçılardan onu farklı kılan bir durumdur.

Eğri çizginin kendi fonksiyonunun dışında psikolojik tarafı da vardır. Farklı sanatçıların desenleri bunun kanıtıdır. Soyut dışa vurumculuk veya 'action painting" örneklerinde elin özgür jestüel hareketinin sonucunda oluşan çizgiler söz konusudur. Eğri çizginin fonksiyonu kromatik olsa da dinamizmini korumaktadır. Bunun örneği Van Gogh'tur. Sanatçının dramatik ruh durumu tabloda dinamik espas olarak görülmektedir (Ailincai, 2010: 133-134).

Burada sanatçının kişiliği çizginin sürekliliğinden okunmaktadır. Aynı ölçüde, aynı mesafede tekrarlanan grup çizgileri monotonluk yaratmadan çizginin hareketinin sürekliliğini vererek obsesif bir kişilik yapısını çağrıştırmaktadır.

\section{4. Kaotik Yapıda Düzensiz Çizgi}

Düzensiz çizgi, kalınken bir anda incelen ya da yok olan, ton değeri koyu iken açılabilen çizgidir. $\mathrm{Bu}$ örnekte kompozisyon içerisindeki çizgilerin toplamı kaotik bir düzen oluşturarak kasvetli, üzgün, hüzünlü ve agresif bir ifade taşımaktadır.

\section{5. Belirli Bir Yöne Doğru Aynı Düzeni Takip Eden Çizgi (Tekrarlanan Ritmik Hareket)}

Suyun akışı gibi bir noktadan yola çıkıp belirli bir yönde devam eden paralel çizgilerin, kimi yerde yoğun kimi yerde seyrek olması, resme belirli bir hacim kazandırmakta, sade ancak vurucu bir ifadenin oluşmasını sağlamaktadır. Bu örnekteki çizgi akışında, hareket belirleyicidir. Çizgilerin takip ettiği yön bir sonuç oluşturmakta ve bu sonuç sanatçının kimliğini belirlemektedir.

Belirli bir yönü takip eden periyodik döngüsel hareketle kendi içerisinde yok olan ya da gelişen, adeta bir helezon etkisi oluşturan çizgilerin tekrarı sanatçının yeni bir form oluşturmak ve portreye ruhsal bir ifade kazandırmak çabasında olduğunu göstermektedir.

\section{SONUÇLAR}

Çizgi, ince-kalın, düz-eğri, açık-koyu, küçük-büyük, kırık yapısı, karakteri, oluşturduğu ritmi ve kompozisyon içerisindeki kurgulanışı ile sanatçının 


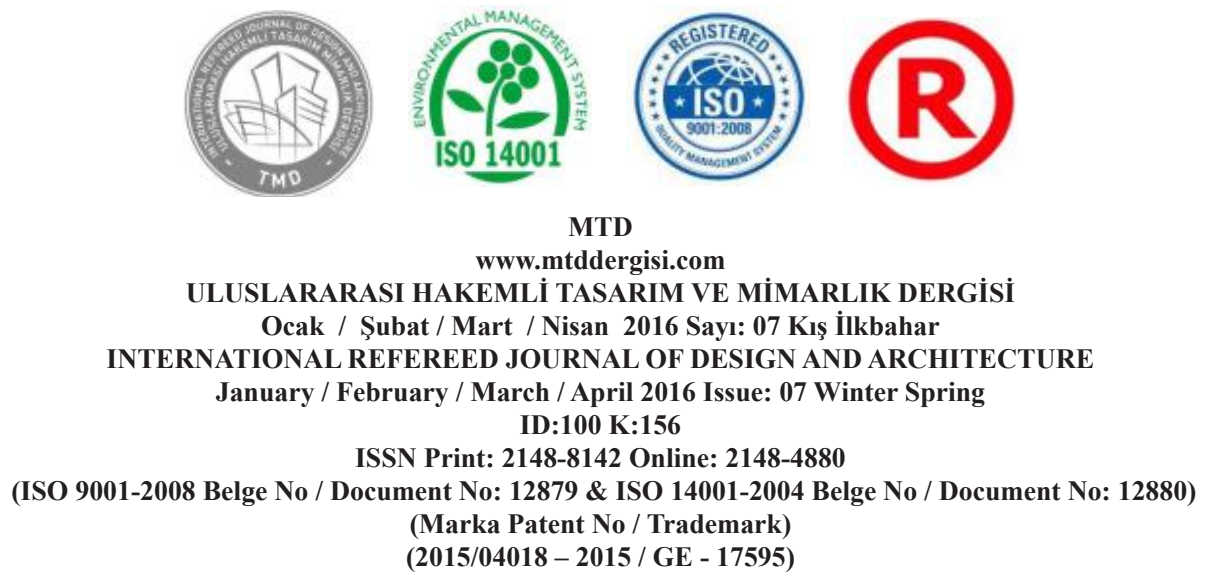

düşünce ve duygularını bir zemin üzerine ifade edebilmesi için tasarımda kullanılan bir elemandır. Ancak her insanın (seyirci) algısına göre çizginin taşıdığı ifade farklı olabilir. Çizginin spontane, dinamik veya monoton niteliklerde oluşması sanatçının kimliğine bağlıdır. Sanatçı, kendi anlayış, anlatım ve üslubuna göre oluşturduğu çizginin karakteri ile her yapıtını sonuçlandırmaktadır. Yukarıda farklı malzeme ve tekniklerle yapılmış örneklerde (tarama ucu, firça, boya ve zemin) sanatçının kimliğinin yine çizgisel olarak ortaya koyduğunu görmekteyiz. Çizginin yapı ve özellikleri sonsuzdur ancak sanatçının jestüel hareketi, psişik enerjisi çizginin oluşumunu etkilediği için çizgiyi modle edilmiş, ince, narin, zayıf, tedirgin, sert, eğri, dekoratif, kesintisiz, masif, spontane, dinamik gibi adlandırmak mümkündür. Bundan başka fonksiyona göre örneğin bir formu sınırlandıran, dekupe eden kontur çizgisi ya da perspektif efekti veren ufuk çizgisi gibi daha net tanımlamalar da yapılmaktadır.

Sanatçının el hareketi ve kullandığı malzeme, sanatçının duygu ve düşüncesi ile birleştiğinde, çizgi canlılık ve kendine özgü özellikler kazanarak belirli bir karakter olușturur. Çizginin karakter farklılığını yaratan malzeme ve sanatçının ruh yapısı, tasarım elemanları ve ilkelerle eserde uyum veya gerilim yaratmaktadır. Resim sanatında çizginin, bir formu sınırlandırmanın dışında, bir yapıtın alt yapısını oluşturmak, sanatçının dünyasını yansıtmak, seyircide tepki uyandırmak, hareket ya da durgunluk etkisi yaratmak gibi işlevleri de vardır. Çizgi, bir kompozisyonun strüktüründe yer alırken, bir desen oluştururken karakteristik bir ifade taşır ve bu sadece çizginin değerinden değil, çizgilerin aralarında kurulan ilişkilerden yararlanilarak da ortaya konulur.

Çizgi, sanatçının iç yapısını yansıttı̆̆ı gibi, izleyicide beğeni veya hoşnutsuzluk gibi duygu durumlarını uyandırmak için bilinçli olarak da kullanılabilmektedir. Kompozisyonda kullanılan çizgilerin vurgulayıcı oluşu seyircide farklı tepki uyandırmaktadır.

\section{KAYNAKLAR}

$A \dot{I L I}$ INCAI, C., (2010). İntroducere in Gramatica Limbajului Vizual, Editura Policrom, Bucureşti

AKAY, B., (1976). Resim Sanatı, Doğuş Matbaas1, Ankara

DORUK, B., (1980). Temel Dizayn Öğretim Programını geliştirme üzerine bir çalışma, İTÜ Mimarlık Fakültesi Baskı Atölyesi

EYÜBOĞLU, B.R., (1986). Resme Başlarken Bütün Eserler 3, Bilgi Yayınevi, Ankara,

$S A N, \dot{I}$. (2008). Sanat ve Eğitim, Ütopya Yay1nevi, Ankara, 2008

SUTTER, D., (1865). Esthetique Generale et Appliquée Contenant les Regles de la Composition dans les Arts Plastiques, Paris, İmprimerie İmpériale 

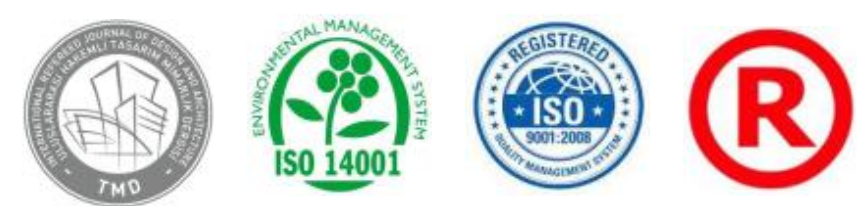

MTD

www.mtddergisi.com

ULUSLARARASI HAKEMLI TASARIM VE MIMARLIK DERGISI

Ocak / Şubat / Mart / Nisan 2016 Sayı: 07 Kıș İlkbahar

INTERNATIONAL REFEREED JOURNAL OF DESIGN AND ARCHITECTURE

January / February / March / April 2016 Issue: 07 Winter Spring ID:100 K:156

ISSN Print: 2148-8142 Online: 2148-4880

(ISO 9001-2008 Belge No / Document No: 12879 \& ISO 14001-2004 Belge No / Document No: 12880)

(Marka Patent No / Trademark)

$(2015 / 04018-2015 /$ GE - 17595)

TANSU $\breve{G}, \boldsymbol{S}$., (1973). Resim Kilavuzu, Milliyet Yayınları, İstanbul

ZARNESCU, C., (2007). Codul Operei lui Brancuşi, Dacia, Cluj-Napoca
WÖLFLLIN, H., (2000). Sanat Tarihinin Temel Kavramları, Remzi Kitapevi, İstanbul

JORDAN, E. MELISSA, (2011) Personality Traits: Theory, Testing and İnfluences, Nova

Science Publishers, İnc., New York 


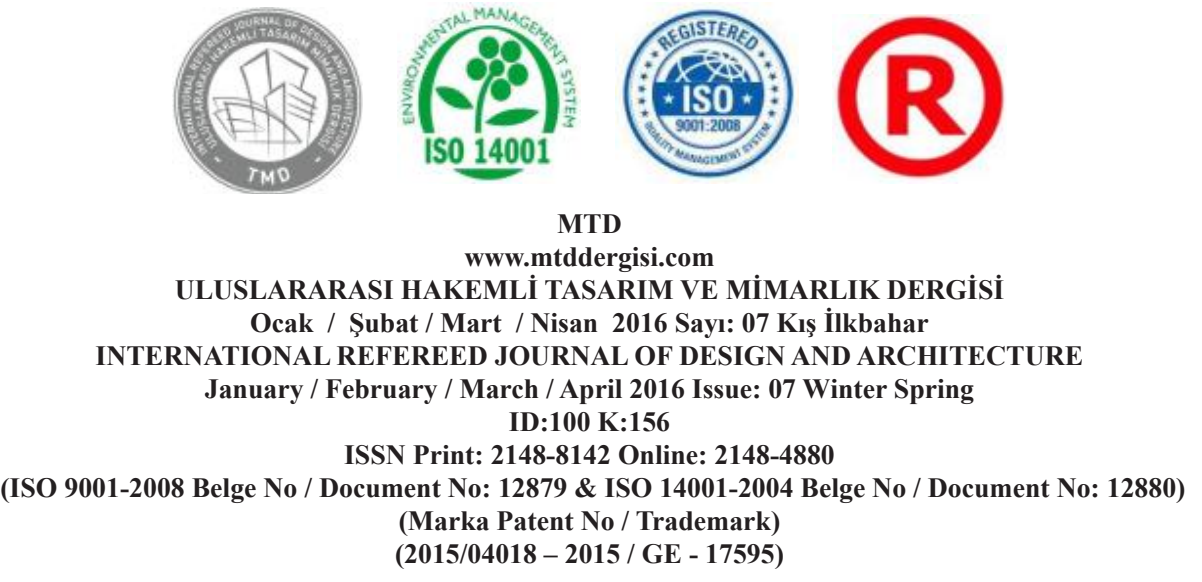

EXTENDED ABSTRACT

The main qualities that shape a work of art include social and historical circumstances, beliefs and thoughts of the society, geographical conditions and also important is the artist's identity. In plastic arts, line, as the main element of the work, plays a great role in reflecting the artist's identity. Despite technological advances and social changes today, line, as an important element of expression, has been a means of communication since antiquity. The design elements that constitute a painting are dots, lines, forms, styles, texture, light, colour, and others, where dot is the intersecting point of two lines, form is the area bordered by lines and gaining volume by the effect of light, texture is the variation obtained by the sum of dots and/or lines in the area, and so on. The present study focuses on line as one of the most important design elements of a work of art, and attempts to analyse the expressive structure of the line as to emphasize the importance of the artist's identity, which generates the character and properties of the line besides the line's different stylistic and directional functions as a design element. The line has form and functions, its form being given by the external space with which it interacts, and in this respect the line displays a large typology, as it could be thin or thick, interrupted or continuous, active or passive, as well as dynamic, emphasized, superficial, etc., depending of the psychological and emotional states of the artist. The expressivity of the line depends also on the material on which the painting is done, as well as on technique and the instruments used in the process of artistic endeavour. The character of the artist depends on social and cultural circumstance of artistic production, but concerning the expression of the artistic individuality, the line is among the most important factors that reflects the identity of the artist, is a way to access his or her subjective experience. The line reveals the character of the artist that transmits the psychic energy. The line, then, deserves to be a concern in art theory and criticism, as our study aims at arguing about by providing a theoretical approach to the line, which is interrelated with a practical approach by focusing on various types of the line as expressed in different paintings. Among them, the spontaneous line in Bob Peak's work, in which the lines interact to produce the dynamic feature of the reflected image corresponding to the dynamic essence of the artist. In Giacometti, the vertical line provides a sense of equilibrium, tranquillity, spiritual rise. Van Gogh's lines are vibrating to express the artist's personality as an obsessive subject attaining rhythm as the main mode of expressivity. George Roulault 

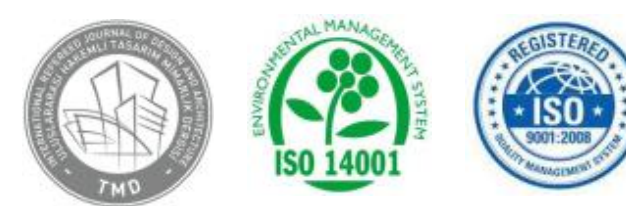

MTD

www.mtddergisi.com

ULUSLARARASI HAKEMLI TASARIM VE MIMARLIK DERGISI

Ocak / Şubat / Mart / Nisan 2016 Sayı: 07 Kıș İlkbahar

INTERNATIONAL REFEREED JOURNAL OF DESIGN AND ARCHITECTURE

January / February / March / April 2016 Issue: 07 Winter Spring ID:100 K:156

ISSN Print: 2148-8142 Online: 2148-4880

(ISO 9001-2008 Belge No / Document No: 12879 \& ISO 14001-2004 Belge No / Document No: 12880)

(Marka Patent No / Trademark)

$(2015 / 04018-2015 /$ GE - 17595)

uses a chaotic line, sometimes interrupted, sometimes continuous, thick as well as hardly visible, by which revealing an artistic personality lacking the spiritual equilibrium. Dalila Ozbay's style consists of the use of repeated lines that constitute a holozoic movement, which denotes a vortex that either supresses the personality or throws it to the explicit apprehension by the viewer. 